\title{
Sistem Pakar Mendiagnosa Penyakit Sampar Menggunakan Metode Hybrid Case Based
}

\author{
Nuraida Br Ginting, Garuda Ginting, Natalia Silalahi \\ Program Studi Teknik Informatika, STMIK Budi Darma, Medan, Indonesia \\ Jalan Sisingamangaraja No. 338, Simp Limun, Medan, Indonesia
}

\begin{abstract}
Abstrak
Penyakit Sampar disebut juga penyakit pest atau black death atau plague, adalah suatu penyakit infeksi bakterial Yersinia pestis (Y.pestis), dimana penyakit ini sebenarnya merupakan penyakit zoonosis yaitu penyakit binatang yang ditularkan manusia. Penyakit ini disebabkan oleh bakteri yersinia pestis yang hidup pada kutu, dimana kutu ini hidup pada binatang pengerat (terutama tikus). Kutu menyebarkan penyakit ketika mengisap darah tikus atau manusia. Penyakit ini disebut juga plague karena bercak-bercak hitam yang terdapat dikulit penderita pada awal kejangkitannya. Penyakit sampar ini pernah menjadi epidemi di tahun 1347-1351 di Eropa dan daerah lainnya dan menewaskan kurang lebih 75 juta jiwa penduduk dunia. Penyakit ini di indonesia masih dalam pemantauan dan termasuk salah satu penyakit menular dalam undang-undang wabah yang harus dilaporkan kepada dinas kesehatan. Menurut WHO penyakit ini merupakan salah satu penyakit menular yang mematikan setelah infeksi dan pasien bisa meninggal dalam waktu 24 jam. Sehingga masyarakat lebih berhati-hati dengan penyakit ini agar tidak terkena penyakit sampar. Karena banyak masyarakat tidak mengenali proses penularan dari infeksi bakterial Yersinia pestis dan tidak mengetahui gejala yang timbul dari penyakit sampar. maka dibuat sistem untuk penyakit sampar yang bertujuan untuk lebih mendiagnosa dini dari penyakit sampar ini. Adapun metode yang diterapkan dalam sistem pakar dan salah satunya adalah hybrid case based. Hybrid case based adalah salah satu teori matematika untuk pembuktian berdasarkan belief functions and plausible reasoning(fungsi kepercayaan dan pemikiran yang masuk akal), yang digunakan untuk mengkombinasikan potongan informasi yang terpisah atau bukti untuk mengkalkulasi suatu kemungkinan dari suatu peristiwa(Arthur P.Dempster dan Glen Shafer).
\end{abstract}

Kata Kunci: Sistem Pakar, Penyakit Sampar, Metode Hybrid Case Based.

\begin{abstract}
Sampar, also known as a pest or black death or plague, is a bacterial infection of Yersinia pestis (Y.pestis), where the disease is actually a zoonotic disease, which is an animal disease transmitted by humans. This disease is caused by the bacterium yersinia pestis which lives on fleas, where these fleas live in rodents (especially mice). Fleas spread disease when sucking rat or human blood. This disease is also called plague due to black patches found in the skin of the patient at the beginning of the outbreak. This pestilence was once an epidemic in 1347-1351 in Europe and other regions and killed approximately 75 million people in the world. This disease in Indonesia is still under monitoring and is one of the infectious diseases in the outbreak law that must be reported to the health office. According to WHO this disease is one of the deadly infectious diseases after infection and patients can die within 24 hours. So that people are more careful with this disease so that they are not exposed to pestilence. Because many people do not recognize the transmission of Yersinia pestis bacterial infections and do not know the symptoms that arise from pestilence. then a system for pestilence is created which aims to better diagnose early onset of this pestilence. The method applied in expert systems and one of them is a case based hybrid. Hybrid case based is one of the mathematical theories for proof based on belief functions and plausible reasoning, which is used to combine separate pieces of information or evidence to calculate a probability of an event (Arthur P.Dempster and Glen Shafer)
\end{abstract}

Keywords: Expert System, Sampar, Hybrid Case Based Method

\section{PENDAHULUAN}

Penyakit Sampar disebut juga penyakit pest atau black death atau plague, adalah suatu penyakit infeksi bakterial Yersinia pestis (Y.pestis), dimana penyakit ini sebenarnya merupakan penyakit zoonosis yaitu penyakit binatang yang ditularkan manusia. Penyakit ini disebabkan oleh bakteri yersinia pestis yang hidup pada kutu, dimana kutu ini hidup pada binatang pengerat (terutama tikus). Kutu menyebarkan penyakit ketika mengisap darah tikus atau manusia. Penyakit ini disebut juga plague karena bercak-bercak hitam yang terdapat dikulit penderita pada awal kejangkitannya. Penyakit sampar ini pernah menjadi epidemi di tahun 1347-1351 di Eropa dan daerah lainnya dan menewaskan kurang lebih 75 juta jiwa penduduk dunia. Penyakit ini di Indonesia masih dalam pemantauan dan termasuk salah satu penyakit menular dalam undang-undang wabah yang harus dilaporkan kepada dinas kesehatan. Menurut WHO penyakit ini merupakan salah satu penyakit menular yang mematikan setelah infeksi dan pasien bisa meninggal dalam waktu $24 \mathrm{jam}$. Sehingga masyarakat lebih berhati-hati dengan penyakit ini agar tidak terkena penyakit sampar. Karena banyak masyarakat tidak mengenali proses penularan dari infeksi bakterial Yersinia pestis dan tidak mengetahui gejala yang timbul dari penyakit sampar. maka dibuat sistem untuk penyakit sampar yang bertujuan untuk lebih mendiagnosa dini dari penyakit sampar ini.

Sistem pakar (Expert System) merupakan cabang dari kecerdasan buatan (Artificial Intelligence) dan juga merupakan bidang ilmu yang muncul seiring perkembangan ilmu komputer saat ini. Sistem ini adalah sistem komputer yang bisa menyamai atau meniru kemampuan seorang pakar [1]. Sistem ini bekerja untuk mengadopsi pengetahuan manusia ke computer yang menggabungkan dasar pengetahuan (Knowledge base) dengan sistem inferensi untuk menggantikan fungsi seorang pakar dalam menyelesaikan masalah [2]. Tujuan utama pengembangan sistem pakar adalah mensubsitusikan pengetahuan dan pengalaman pakar di berbagai bidang. 
Pengetahuan yang dimiliki sistem ini merupakan hasil diagnosa dari penyakit yang diderita oleh penderita, dan pengetahuan ini akan digunakan sebagai acuan untuk mengetahui apakah penderita tersebut mengidap penyakit atau tidak,tanpa harus membawa tersebut kepada ahli atau pakar langsung.

Adapun metode yang diterapkan dalam sistem pakar dan salah satunya adalah hybrid case based. Hybrid case based adalah salah satu teori matematika untuk pembuktian berdasarkan belief functions and plausible reasoning(fungsi kepercayaan dan pemikiran yang masuk akal), yang digunakan untuk mengkombinasikan potongan informasi yang terpisah atau bukti untuk mengkalkulasi suatu kemungkinan dari suatu peristiwa.

Metode Hybrid Case Based pernah diterapkan pada aplikasi sistem pakar seperti penelitian oleh Dedy Hidayat Kusuma, Moh Nur Shodiq dengan judul "Sistem Rekomendasi Destinasi Pariwisata Menggunakan Metode Hibrid Case Based Reasoning dan Location Based Service Sebagai Pemandu Wisatawan di Banyuwangi", dari hasil penelitian bahwa hybrid case based adalah sebuah sistem rekomendasi. Sistem rekomendasi yang diusulkan dalam penelitian menggunakan kombinasi metode case-based reasoning $(C B R)$ dan location based. Sistem yang dibangun nantinya dapat diakses wisatawan dalam bentuk aplikasi mobile.

\section{TEORITIS}

\subsection{Penyakit Sampar}

Pes atau sampar (plague) adalah penyakit yang disebabkan oleh infeksi bakteri bernama Yersinia pestis. Penyakit ini dikenal juga dengan istilah wabah hitam (black death). Bakteri ini dapat menyebabkan kematian jika tidak segera ditangani. Selain itu, penyakit ini juga dapat menyebar dari kotoran ke mulut (fecal-oral transmission), melalui droplet batuk atau bersin, dan akibat kontak secara langsung dengan pemilik wabah, baik manusia atau hewan. Pes pada manusia juga dapat berasal dari cakaran kucing atau anjing yang telah terinfeksi, termasuk melalui luka yang terkena darah hewan yang terinfeksi.

\subsection{Hybrid Case Based}

Hybrid case based adalah sebuah sistem rekomendasi penelitian yang menggunakan kombinasi (hybrid) metode case-based reasoning dan location based. Sistem yang dibangun dalam bentuk aplikasi mobile berbasis android berupa preferensi yang didasari pada koordinat GPS dibandingkan dengan atribut obyek yang tersimpan pada sistem dengan menggunakan metode similaritas nearest neighbor.

Jaccard adalah suatu indeks yang menunjukan derajat kesamaan antara suatu himpunan set data yang lain. Dengan demikian nilai dari jaccard dapat diperoleh dari suatu irisan dari kedua himpunan dibagi dengan nilai gabungannya.Berikut rumus dari similarity :

$$
\operatorname{sim}(S, T) z\left(\frac{\sum_{\mathrm{i}}^{\mathrm{n}}=1 f_{i}\left(S_{i}, T_{i}\right) * w_{i}}{\sum_{\mathrm{i}}^{\mathrm{n}}=1 w_{i}}\right)
$$

\section{ANALISA DAN PEMBAHASAN}

Dalam tahapan ini dilakukan pencarian dan pengumpulan data serta pengetahuan yang diperoleh dari pakar. Sehingga analisa mendapat informasi mengenai penyakit sampar yang disebabkan oleh bakteri yang disebut Yersinia pestis bakteri ini dikenal juga mematikan jika tidak segera ditangani oleh pakarnya. Selain itu penyakit ini juga menyebar dari kotoran kemulut melalui batuk atau bersin, yang berakibat kontak secara langsung dengan penderita wabah, baik manusia ataupun hewan. Adapun gejala-gejala yang dibahas adalah sebagai berikut :

Tabel 3. Gejala Penyakit Sampar

\begin{tabular}{lll}
\hline Kode & Gejala Penyakit & Nilai Pakar \\
\hline 1001 & Rasa nyeri pada daerah Kuku & 0.8 \\
1002 & Merah pada bagian Kuku & 0.8 \\
1003 & Bengkak pada daerah Kuku & 0.6 \\
1004 & Panas pada otot sekitar kuku & 0.6 \\
1005 & Beberapa saat setelah bengkak keluar nanah & 0.6 \\
1006 & Penderita sampar akan mengalami demam & 0.4 \\
1007 & Penderita sampar akan mengalami Lemas & 0.4 \\
& pada otot kaki & 0.6 \\
1008 & Warna kulit kuku menghitam & 0.4 \\
1009 & Penderita mengalami Gemetar & 0.4 \\
1010 & Penderita akan mual muntah & \\
\hline
\end{tabular}

Sumber: Dr.Aprina Sari Harahap

Dari tabel diatas maka dipersentasikan seperti rule dibawah ini. Refresentasi ini digunakan untuk memperoleh pencarian dan menentukan kesimpulan diagnosa, berikut ini adalah pembahasannya. 


\subsection{Rule Based Reasoning}

Rule Based Reasoning (RBR) merupakan aturan-aturan logis di mana setiap aturannya didapat dari studi literatur dan informasi dari ahli tanpa melihat kasus yang dihadapi. Implementasi Rule Based Reasoning akan dilakukan saat pencocokan gejala pasien yang terindikasi gejalapenyakit. Gejala-gejala tersebut dicocokan dengan literatur berklausa if, dan mendapatkan output binary yang nantinya akan dilihat kecocokannya antara penyakit satu dengan penyakit lainnya.

Tabel 2. Data Analisis Gejala Pasien Sampar

\begin{tabular}{ccccccccccc}
\hline \multirow{2}{*}{ Kode Pasien } & G1 & G2 & G3 & G4 & G5 & G6 & G7 & G8 & G9 & G10 \\
\hline Asep & $\checkmark$ & $\checkmark$ & $\checkmark$ & & $\checkmark$ & & & $\checkmark$ & & $\checkmark$ \\
Rika & $\checkmark$ & & $\checkmark$ & & $\checkmark$ & $\checkmark$ & & $\checkmark$ & & $\checkmark$ \\
Meta & $\checkmark$ & $\checkmark$ & $\checkmark$ & & & & & & & $\checkmark$ \\
Melda & $\checkmark$ & & & $\checkmark$ & $\checkmark$ & & & $\checkmark$ & & $\checkmark$ \\
Oliv & $\checkmark$ & & $\checkmark$ & & $\checkmark$ & $\checkmark$ & & & & $\checkmark$ \\
Icha & $\checkmark$ & $\checkmark$ & $\checkmark$ & & $\checkmark$ & $\checkmark$ & $\checkmark$ & $\checkmark$ & & $\checkmark$ \\
Siska & $\checkmark$ & & $\checkmark$ & & & & & $\checkmark$ & $\checkmark$ & $\checkmark$ \\
Wahyu & $\checkmark$ & $\checkmark$ & $\checkmark$ & $\checkmark$ & & & & $\checkmark$ & & \\
Remita & $\checkmark$ & & & & $\checkmark$ & $\checkmark$ & & $\checkmark$ & & $\checkmark$ \\
Erica & $\checkmark$ & $\checkmark$ & $\checkmark$ & & & & $\checkmark$ & & & $\checkmark$ \\
\hline
\end{tabular}

\subsection{Case Based Reasoning}

Case Based Reasoning (CBR) adalah salah satu penyelesaian masalah, di mana masalah tersebut diselesaikan dengan melihat pola atau keadaan yang telah terjadi sebelumnya. Secara formal, CBR mempunyai 4 langkah utama, yaitu: retrieve, reuse, revise, dan retain. Dengan demikian, jika ada permasalahan yang mirip dengan kasus tersebut, solusinya sudah ditemukan.

Implementasi Case Based Reasoning akan dilakukan saat pencocokan gejala pasien yang terindikasi gejala penyakit. Gejala-gejala tersebut dicocokan dengan kasus-kasus sebelumnya dimana kasus tersebut dikumpulkan sebagai binary point, hasil dari Case Based Reasoning ini akan mengeluarkan output binaryyang nantinya akan dilihat kecocokannya antara penyakit satu dengan penyakit lainnya.

IF Rasa nyeri pada daerah Kuku

AND Bengkak pada daerah Kuku

AND Merah pada bagian kuku

AND Panas pada otot sekitar kuku

AND Beberapa saat setelah bengkak keluar nanah

AND Penderita sampar akan mengalami demam

AND Penderita sampar akan mengalami Lemas pada otot kaki

AND Warna kulit kuku menghitam

AND Penderita mengalami Gemetar

THEN penyakit Sampar.

Tabel 3. Data Analisis Gejala Pasien Sampar

\begin{tabular}{lll}
\hline Kode & Rule & Diagnosa \\
\hline P1 & G1,G2,G3,G5,G8,G10 & Sampar \\
P2 & G1,G3,G5,G6,G8,G10 & Sampar \\
P3 & G1,G2,G3,G10, & Sampar \\
P4 & G1,G4,G5,G8,10 & Sampar \\
P5 & G1,G3,G5,G6,10 & Sampar \\
P6 & G1,G2,G3,G5,G6,G7,G8,G10 & Sampar \\
P7 & G1,G3,G8,G9,G10 & Sampar \\
P8 & G1,G2,G3,G4,G8 & Sampar \\
P9 & G1,G5,G6,G8,G10 & Sampar \\
P10 & G1,G2,G3,G7,G10 & Sampar \\
\hline
\end{tabular}

Dalam mengeksperesikan derajat kepastian, untuk mengasumsikan derajat kepastian seorang pakar terhadap suatu data. Konsep ini kemudian diformulasikan dalam rumus-rumus dasar. Menerapkan sistem Hybrid case based dalam mendiagnosa penyakit Sampar yaitu : 
JURNAL MEDIA INFORMATIKA BUDIDARMA, Vol 3, No 1, Januari 2019

ISSN 2614-5278 (media cetak)

ISSN 2548-8368 (media online)

Hal: 65 - 71 | DOI: 10.30865/mib.v3i1.1062

Tabel 4. Menentukan nilai Hybrid Case Based

\begin{tabular}{ccccccccccc}
\hline \multirow{2}{*}{ Kode Pasien } & G1 & G2 & G3 & G4 & G5 & G6 & G7 & G8 & G9 & G10 \\
\hline P1 & 1 & 1 & 1 & 0 & 1 & 0 & 0 & 1 & 0 & 1 \\
P2 & 1 & 0 & 1 & 0 & 1 & 1 & 0 & 1 & 0 & 1 \\
P3 & 1 & 1 & 1 & 0 & 1 & 1 & 0 & 0 & 0 & 1 \\
P4 & 1 & 0 & 0 & 1 & 1 & 0 & 0 & 1 & 0 & 1 \\
P5 & 1 & 0 & 1 & 0 & 1 & 1 & 0 & 0 & 0 & 1 \\
P6 & 1 & 1 & 1 & 0 & 1 & 1 & 1 & 1 & 0 & 1 \\
P7 & 1 & 0 & 1 & 0 & 0 & 0 & 0 & 1 & 1 & 1 \\
P8 & 1 & 1 & 1 & 1 & 0 & 0 & 0 & 1 & 0 & 0 \\
P9 & 1 & 0 & 0 & 0 & 1 & 1 & 0 & 1 & 0 & 1 \\
P10 & 1 & 1 & 1 & 0 & 0 & 0 & 1 & 0 & 0 & 1 \\
\hline
\end{tabular}

Maka pada user $=\mathrm{A}$

Maka pada pasien $=\mathrm{B}$

$\mathrm{A}=0,4|0,4| 0,6|0,6| 0,4|0,6| 0,4|0,4| 0,4|0,4|$

$\mathrm{B}=\mathrm{B} 1=1,1,1,0,1,0,0,1,0,1$

$\mathrm{B} 2=1,0,1,0,1,1,0,1,0,1$

$\mathrm{B} 3=1,1,1,0,1,1,0,0,0,1$

$\mathrm{B} 4=1,0,0,1,1,0,0,1,0,1$

B5 $=1,0,1,0,1,1,0,0,0,1$

B6 $=1,1,1,0,1,1,1,1,0,1$

$\mathrm{B} 7=1,0,1,0,0,0,0,1,1,1$

$\mathrm{B} 8=1,1,1,1,0,0,0,1,0,0$

B9 $=1,0,0,0,1,1,0,1,0,1$

$\mathrm{B} 10=1,1,1,0,0,0,1,0,0,1$

$$
\begin{gathered}
\sum i=1(A i * B 1)=(0,4 * 1)+(0,4 * 1)+(0,4 * 1)+(0,6 * 0)+(0,4 * 1)+(0,6 * 0) \\
+(0,4 * 0)+(0,4 * 0)+(0,4 * 0)+(0,4 * 1) \\
=2
\end{gathered}
$$

$\left.\sqrt{\sum \frac{n}{i=1} \mathrm{~A}_{i}^{2} \cdot \sum_{i=n}^{n} \mathrm{~B} 1^{2}=\left(0,4^{2}+0,4^{2}+0,4^{2}\right.}+0,6^{2}+0,4^{2}+0,4^{2}+0,4^{2}+0,6^{2}+0,4^{2}+0,4^{2}\right) *(1+1$ $+1+0+1+0+0+1+0+1)$

$$
=2 * 6=12
$$

$\frac{\sum_{i}^{n}=\mid(A i-B i)}{\sqrt{\sum_{i}^{n}=A_{i}^{n}-\sum_{i}^{n}=\mid B_{i}^{n}=}}=\frac{2}{\sqrt{12}}=\frac{2}{3,4}=0,58=58 \%$

$\sum i=1(A i * B 2)=(0,4 * 1)+(0,4 * 0)+(0,4 * 1)+(0,6 * 0)+(0,4 * 1)+(0,6 * 1)$

$$
+(0,4 * 0)+(0,4 * 1)+(0,4 * 0)+(0,4 * 1)
$$

$$
=2,6
$$

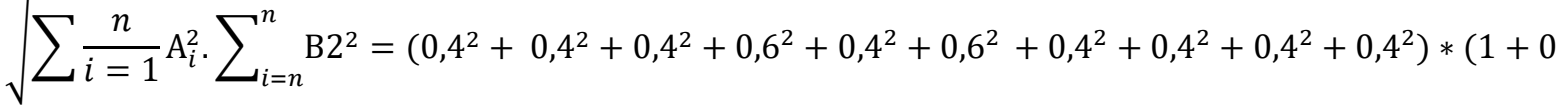

$$
+1+0+1+1+0+1+0+1)
$$

$$
=2 * 6=12
$$

$\frac{\sum_{i}^{n}=\mid(A i-B 2)}{\sqrt{\sum_{i}^{n}=A_{i}^{n}-\sum_{i}^{n}=\mid B_{i}^{n}=}}=\frac{2,6}{\sqrt{12}}=\frac{2,6}{3,4}=0,76=76 \%$

$$
\begin{gathered}
\sum i=1(A i * B 3)=(0,4 * 1)+(0,4 * 1)+(0,4 * 1)+(0,6 * 0)+(0,4 * 1)+(0,6 * 1) \\
+(0,4 * 0)+(0,4 * 0)+(0,4 * 0)+(0,4 * 1) \\
=2,6
\end{gathered}
$$

$$
\begin{gathered}
\left.\sqrt{\sum \frac{n}{i=1} \mathrm{~A}_{i}^{2} \cdot \sum_{i=n}^{n} \mathrm{~B}^{2}=\left(0,4^{2}+0,4^{2}+0,4^{2}\right.}+0,6^{2}+0,4^{2}+0,6^{2}+0,4^{2}+0,4^{2}+0,4^{2}+0,4^{2}\right) *(1+1 \\
+1+0+1+1+0+0+0+1) \\
=2 * 6=12
\end{gathered}
$$


JURNAL MEDIA INFORMATIKA BUDIDARMA, Vol 3, No 1, Januari 2019

ISSN 2614-5278 (media cetak)

ISSN 2548-8368 (media online)

Hal: 65 - 71 | DOI: 10.30865/mib.v3i1.1062

$$
\begin{gathered}
\sum_{i}^{n}=\mid(A i-B 3) \\
\sqrt{\sum_{i}^{n}=A_{i}^{n}-\sum_{i}^{n}=\mid B_{i}^{n}=}=\frac{2,6}{\sqrt{12}}=\frac{2,6}{3,4}=0,76=76 \% \\
\sum i=1(A i * B 4)=(0,4 * 1)+(0,4 * 0)+(0,6 * 0)+(0,6 * 1)+(0,4 * 1)+(0,6 * 0) \\
+\begin{array}{c}
(0,4 * 0) \\
=2,2
\end{array}
\end{gathered}
$$

$$
\begin{aligned}
& \sqrt{\sum \frac{n}{i=1} \mathrm{~A}_{i}^{2} \cdot \sum_{i=n}^{n} \mathrm{~B} 4^{2}=\left(0,4^{2}+0,4^{2}+0,6^{2}+0,6^{2}+0,4^{2}+0,6^{2}+0,4^{2}+0,8^{2}+0,4^{2}+0,4^{2}\right) *(1+0} \\
& +0+1+1+0+0+1+0+1) \\
& =2 * 5=10 \\
& \frac{\sum_{i}^{n}=\mid(A i-B i)}{\sqrt{\sum_{i}^{n}=A_{i}^{n}-\sum_{i}^{n}=\mid B_{i}^{n}=}}=\frac{2,2}{\sqrt{10}}=\frac{2,2}{3,16}=0,69=69 \% \\
& \sum i=1(A i * B 5)=(0,4 * 1)+(0,4 * 0)+(0,4 * 1)+(0,6 * 0)+(0,4 * 1)+(0,6 * 1) \\
& +(0,4 * 0)+(0,4 * 0)+(0,4 * 0)+(0,4 * 1) \\
& =2,2
\end{aligned}
$$$$
\left.\sqrt{\sum \frac{n}{i=1} \mathrm{~A}_{i}^{2} \cdot \sum_{i=n}^{n} \mathrm{~B}^{2}=\left(0,4^{2}+0,4^{2}+0,6^{2}\right.}+0,6^{2}+0,4^{2}+0,6^{2}+0,4^{2}+0,8^{2}+0,6^{2}+0,4^{2}\right) *(1+0
$$$$
=2 * 5=10
$$$$
\frac{\sum_{i}^{n}=\mid(A i-B 5)}{\sqrt{\sum_{i}^{n}=A_{i}^{n}-\sum_{i}^{n}=\mid B_{i}^{n}=}}=\frac{2,2}{\sqrt{10}}=\frac{2,2}{3,16}=0,69=69 \%
$$$$
\sum i=1(A i * B 6)=(0,4 * 1)+(0,4 * 1)+(0,4 * 1)+(0,6 * 0)+(0,4 * 1)+(0,6 * 1)
$$$$
+(0,4 * 1)+(0,4 * 1)+(0,4 * 0)+(0,4 * 1)
$$$$
=3,4
$$$$
\left.\sqrt{\sum \frac{n}{i=1} \mathrm{~A}_{i}^{2} \cdot \sum_{i=n}^{n} \mathrm{~B} 6^{2}=\left(0,4^{2}+0,4^{2}+0,4^{2}\right.}+0,6^{2}+0,4^{2}+0,6^{2}+0,4^{2}+0,4^{2}+0,4^{2}+0,4^{2}\right) *(1+1
$$$$
+1+0+1+1+1+1+0+1)
$$$$
=2 * 8=16
$$

$\frac{\sum_{i}^{n}=\mid(A i-B 6)}{\sqrt{\sum_{i}^{n}=A_{i}^{n}-\sum_{i}^{n}=\mid B_{i}^{n}=}}=\frac{3,4}{\sqrt{16}}=\frac{3,4}{4}=0,85=85 \%$

$$
\begin{gathered}
\sum i=1(A i * B 7)=(0,4 * 1)+(0,4 * 0)+(0,4 * 1)+(0,6 * 0)+(0,4 * 0)+(0,8 * 0) \\
+(0,4 * 0)+(0,4 * 1)+(0,4 * 1)+(0,4 * 1) \\
=2
\end{gathered}
$$

$$
\begin{gathered}
\left.\sqrt{\sum \frac{n}{i=1} A_{i}^{2} \cdot \sum_{i=n}^{n} \mathrm{~B}^{2}=\left(0,4^{2}+0,4^{2}+0,4^{2}\right.}+0,6^{2}+0,4^{2}+0,6+0,4^{2}+0,4^{2}+0,4+0,4^{2}\right) *(1+0 \\
+1+0+0+0+0+1+1+1) \\
=2 * 5=10 \\
\sqrt{\sum_{i}^{n}=A_{i}^{n}-\sum_{i}^{n}=\mid B_{i}^{n}=}=\frac{2}{\sqrt{10}}=\frac{2}{3,16}=0,63=63 \%
\end{gathered}
$$

$$
\begin{gathered}
\sum i=1(A i * B 8)=(0,4 * 1)+(0,4 * 1)+(0,4 * 1)+(0,6 * 1)+(0,4 * 0)+(0,6 * 0) \\
+(0,4 * 0)+(0,4 * 1)+(0,4 * 0)+(0,4 * 0) \\
=2,2
\end{gathered}
$$

$$
\begin{gathered}
\left.\sqrt{\sum \frac{n}{i=1} \mathrm{~A}_{i}^{2} \cdot \sum_{i=n}^{n} \mathrm{~B}^{2}=\left(0,4^{2}+0,4^{2}+0,4^{2}\right.}+0,6^{2}+0,4^{2}+0,6^{2}+0,4^{2}+0,4^{2}+0,4^{2}+0,4^{2}\right) *(1+1 \\
+1+1+0+0+0+1+0+0) \\
=2 * 5=10
\end{gathered}
$$




$$
\begin{aligned}
& \frac{\sum_{i}^{n}=\mid(A i-B 8)}{\sqrt{\sum_{i}^{n}=A_{i}^{n}-\sum_{i}^{n}=\mid B_{i}^{n}=}}=\frac{2,2}{\sqrt{10}}=\frac{2,2}{3,16}=0,69=69 \% \\
& \sum i=1(A i * B 9)=(0,4 * 1)+(0,4 * 0)+(0,4 * 0)+(0,6 * 0)+(0,4 * 1)+(0,6 * 1)+(0,4 * 0) \\
& =2,2 \\
& +(0,4 * 1)+(0,4 * 0)+(0,4 * 1) \\
& \begin{array}{c}
\sqrt{\sum \frac{n}{i=1} \mathrm{~A}_{i}^{2} \cdot \sum_{i=n}^{n} \mathrm{~B} 9^{2}=\left(0,4^{2}+0,4^{2}+0,4^{2}+0,6^{2}+0,4^{2}+0,6+0,4^{2}+0,4^{2}+0,4^{2}+0,4^{2}\right) *(1+0} \\
+0+0+1+1+0+1+0+1) \\
=2 * 5=10
\end{array} \\
& \frac{\sum_{i}^{n}=\mid(A i-B 9)}{\sqrt{\sum_{i}^{n}=A_{i}^{n}-\sum_{i}^{n}=\mid B_{i}^{n}=}}=\frac{2,2}{\sqrt{10}}=\frac{2,2}{3,16}=0,69=69 \% \\
& \sum i=1(A i * B 10)=(0,4 * 1)+(0,4 * 1)+(0,4 * 1)+(0,6 * 0)+(0,4 * 0)+(0,6 * 0) \\
& +(0,4 * 1)+(0,4 * 0)+(0,4 * 0)+(0,4 * 1) \\
& =2 \\
& \left.\sqrt{\sum \frac{n}{i=1} \mathrm{~A}_{i}^{2} \cdot \sum_{i=n}^{n} \mathrm{~B} 10^{2}=\left(0,4^{2}+0,4^{2}+0,4^{2}\right.}+0,6^{2}+0,4^{2}+0,6+0,4^{2}+0,4^{2}+0,4^{2}+0,4^{2}\right) *(1+1 \\
& +1+0+0+0+1+0+0+1) \\
& =2 * 5=10 \\
& \frac{\sum_{i}^{n}=\mid(A i-B 10)}{\sqrt{\sum_{i}^{n}=A_{i}^{n}-\sum_{i}^{n}=\mid B_{i}^{n}=}}=\frac{2}{\sqrt{10}}=\frac{2}{3,16}=0,63=63 \%
\end{aligned}
$$

Dari perhitungan diatas, gejala yang telah di jawab oleh pengguna/user masing-masing tahap memiliki nilai sebagai berikut:

Tahap $1: 58 \%$

Tahap $2: 76 \%$

Tahap $3: 76 \%$

Tahap $4: 69 \%$

Tahap $5: 69 \%$

Tahap $6: 85 \%$

Tahap $7: 63 \%$

Tahap $8: 69 \%$

Tahap $9: 69 \%$

Tahap $10: 63 \%$

Pada hasil di atas gejala yang telah dijawab oleh pengguna/ user menggunkan nilai presentase memiliki nilai yang sudah mendekati berdasarkan kasus yang telah terjadi sebelumnya pada nilai tertinggi pada tahap 6 dengan nilai 0.85 atau dalam bentuk persen adalah $85 \%$.

\section{KESIMPULAN}

Setelah penulis melakukan penelitian dan juga berdasarkan referensi-referensi yang ada, data dan hasil analisa serta melalui fakta yang telah diuraikan pada bab-bab terdahulu, maka penulis mengangkat kesimpulan sebagai berikut:

1. Mendiagnosa penyakit Sampar pada manusia dengan sistem pakar melihat dari gejala-gejala yang dialami dapat dilakukan untuk membantu masyarakat khususnya bagi masyarakat untuk mengetahui penyakit Sampar pada manusia.

2. Dengan menerapkan Metode Hybrid Case Based dalam meniagnosa penyakit Sampar pada manusia dapat menghasilkan perhitungan valid yang sama dengan perhitungan manual sehingga proses diagnosa dapat dilakukan dengan cepat dan akurat. 


\section{REFERENCES}

[1] Anita Desiani and Muhammad Arhami, Konsep Kecerdasan Buatan. Yogyakarta: Penerbit : Andi, 2006.

[2] Muhammad Dahira, "Kecerdasan Buatan(Artificial Intelligence)," Saintikom, vol. 5, no. 2, p. 185, Agustus 2008

[3] Nasri, "Artificial Intellegence," vol. 1, no. 2, p. 4, Desember 2014.

[4] Hamdani, "Sistem pakar untuk diagnosa penyakit mata pada manusia," Informatika Mulawarman, vol. 5, no. 2, p. 13, Juli 2010.

[5] Muhammad Dahira, "Pengembangan sistem pakar dalam suatu aplikasi," Saintikom, vol. 10, no. 3, p. 199, September 2011.

[6] T Sutojo, Edy Mulyanto, and Vincent Suhartono, Kecerdasan Buatan. Yogyakarta: Penerbit : Andi, 2011.

[7] N.A. Hasibuan, K. Yusmiarti, F.T. Waruwu, R. Rahim, Expert systems with genetics probability, Int. J. Res. Sci. Eng. 3 (2017) 112116.

[8] M. Mesran, M. Syahrizal, S. Suginam, N. Kurniasih, A.D. Gs, A.S. Ahmar, R. Rahim, Expert System for Disease Risk Based on Lifestyle with Fuzzy Mamdani, Int. J. Eng. Technol. 7 (2018) 88-91. doi:10.14419/ijet.v7i2.3.12622.

[9] Dedy Hidayat Kusuma and Moh Nur Shodiq, "Sistem Rekomendasi Destinasi Pariwisata Menggunakan Metode Hybrid Case Based Reasoning dan Location Based Service sebagai pemandu Wisatawan di Banyuwangi," Jurnal INTENSIF, vol. Vol 1, no. 1, pp. 30,31,32, Febuari 2017.

[10] Kasnodihardjo, Rachmalina Soerachman, and Sunanti Zalbawi S, "Studi Tentang penyakit pes dengan pendekatan sosioekologi di dusun sulorowo, perbukitan tengger bromo, Kabupaten pasuruan , jawa timur," vol. XV, no. 1, pp. 35,36, 2005

[11] A Halim Mubin, Panduan Praktis Ilmu Penyakit Dalam. Jakarta: Penerbit Buku Kedokteran EGC, 2006.

[12] M. Syahril, N.A. Hasibuan, P. Pristiwanto, PENERAPAN METODE DEMPSTER SHAFER DALAM MENDIAGNOSA PENYAKIT BELL'S PALSY, JURIKOM (Jurnal Ris. Komputer). $3 \quad$ (2016). http://ejurnal.stmikbudidarma.ac.id/index.php/jurikom/article/view/182/164 (accessed June 23, 2017).

[13] I. Sumatorno, D. Arisandi, A.P.U. Siahaan, M. Mesran, Expert System of Catfish Disease Determinants Using Certainty Factor Method, Int. J. Recent Trends Eng. Res. 3 (2017) 202-209. doi:10.23883/IJRTER.2017.3405.TCYZ2.

[14] Rosa A S and M Shalahuddin, Rekayasa Perangkat Lunak. Bandung: Penerbit : Informatika, 2013.

[15] Rahmat Priyanto, Langsung Bisa Visual Basic.net 2008. Yogyakarta: Penerbit : Andi, 2009.

[16] Primanda Arif Aditya, Dasar-dasar Pemograman Database Dekstop dengan Visual Basic.NET 2008. Jakarta: Penerbit : PT. Alex Media Komputindo, 2013. 